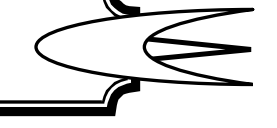

\title{
Synthesis, Characterization Of Various Coumarin Derivatives
}

\author{
Jamal M. Hamid \\ Department of Biochemistry / College of Ninevah medicine \\ University of Mosul
}

Received

$20 / 09 / 2011$
Accepted

$08 / 12$ / 2011

\begin{abstract}
الخلاصة
في هذه الدراسة تم تحضير 3-اسيتايل الكومارين (1) من مفاعلة السالسيلديهايد مع العهائ

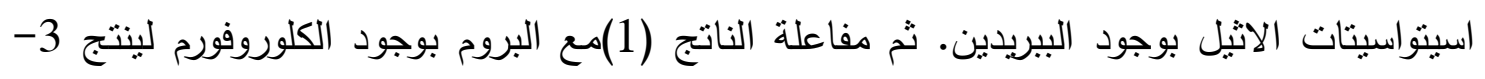
(2-برومو اسيتايل كومارين)(2). مركب (3) يحضر بمفاعلة المركب (2) مع الايميدازول لينتج الينج

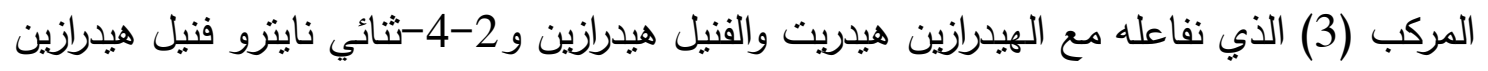

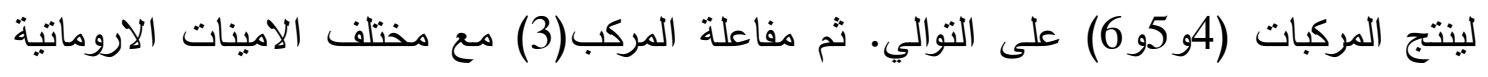
والاليفاتية لينتج المركبات (7-75). شخصت المركبات الناتجة بواسطة الطرائق الفيزياوية والتحليلات الطيفية المتوفرة (IR,U.V).
\end{abstract}

\begin{abstract}
3 -acetyl coumarin (1) was prepared by reacting salicyldehyde with ethylacetoacetate.3-(2-bromoacetyl coumarin (2) was also prepared by reacting 3-acetyl coumarin with bromine in chloroform solution. Reaction of compound (2) with imidazol in dioxan solution to gave $3-(1 \mathrm{H}$-imidazol1yl-acetyl) coumarin(3). Compounds $(4,5,6)$ were synthesized by the reaction of compound (3) with hydrazine hydrate, phenyl hydrazine, 2,4dinitro-phenylhydrazine respectively. Compound (7-15) were synthesized by the reaction of compound (3) with various aromatic and aliphatic amines. The structures of all the synthesized compounds have been established on the basis of physical, spectral (IR, U.V) data.
\end{abstract}

Key words: different coumarin, derived imidazole, schiffbase,phenyl hydrazine coumarin. 


\section{Introduction}

Coumarins owe their class name to 'Coumarou', the vernacular name of the tonka bean (Dipteryx odorata Willd., Fabaceae), from which coumarin itself was isolated in 1820[1]. Coumarin is classified as a member of the benzopyrone family of compounds, all of which consist of a benzene ring joined to a pyrone ring [2]. The benzopyrones can be subdivided into the benzo-a-pyrones to which the coumarins belong and the benzo-gpyrones, of which the flavonoids are principal members (Fig. 1.1).<smiles>O=c1ccc2ccccc2o1</smiles>

[A] a-Benzopyrone<smiles>O=c1ccoc2ccccc12</smiles>

[B] g-Benzopyrone

Fig. (1.1): The chemical structures of benzopyrone subclasses, with the basic coumarin structure (benzo-a-pyrone) $[\mathrm{A}]$, and flavonoid (benzo-g-pyrone) structure [B].

There are four main coumarin sub-types: the simple coumarins, furanocoumarins, pyranocoumarins and the pyrone-substituted coumarins (The simple coumarins (e.g. coumarin, 7-hydroxycoumarin and 6,7dihydroxycoumarin), are the hydroxylated, alkoxylated and alkylated derivatives of the parent compound, coumarin, along with their glycosides. Furanocoumarins consist of a five-membered furan ring attached to the coumarin nucleus, divided into linear or angular types with substituents at one or both of the remaining benzoid positions. Pyranocoumarin members are analogous to the furanocoumarins, but contain a six-membered ring. Coumarins substituted in the pyrone ring include 4-hydroxycoumarin [3]. The synthetic compound, warfarin, belongs to this coumarin subtype. By virtue of its structural simplicity coumarin has been assigned as head of the benzo-a-pyrones, although it is generally accepted that 7-hydroxycoumarin be regarded as the parent compound of the more complex coumarins Genistein is an isoflavone and belongs to the benzo-g- pyrones. It is a natural component of soy and has been intensively investigated as a chemopreventitive agent,mainly against hormonally regulated breast and 
prostate cancers in animal models [5]. Coumarins comprise a very large class of compounds found throughout the plant kingdom [6-8]. They are found at high levels in some essential oils, particularly cinnamon bark oil $(7,000 \mathrm{ppm})$, cassia leaf oil (up to 87,300 ppm) and lavender oil. Coumarin is also found in fruits (e.g. bilberry, cloudberry), green tea and other foods such as chicory [9]. Most coumarins occur in higher plants, with the richest sources being the Rutaceae and Umbelliferae. Although distributed throughout all parts of the plant, the coumarins occur at the highest levels in the fruits, followed by the roots, stems and leaves. Environmental conditions and seasonal changes can influence the occurrence in diverse parts of the plant [3]. Recently six new minor coumarins have been isolated from the fruits and the stem bark of Calophyllum dispar (Clusiaceae). The genus Calophyllum, which comprises 200 species, is widely distributed in the tropical rain forest where several species are used in folk medicine [10]. Although most of the natural coumarins in existence have been isolated from the higher plants, some members have been discovered in microorganisms Some important coumarin members have been isolated from microbial sources e.g. novobiocin and coumermycin from Streptomyces, and aflatoxins from Aspergillus species $[11,12]$. The aflatoxins are a group of highly toxic fungal metabolites and the most commonly occurring member of the group is aflatoxin B1 [3].

\section{Experimental}

\section{Chemicals and instrumentation}

All chemicals were purchased from Flucka and BDH chemical Ltd. The melting points were measured on an electrothermal 9300 engineering Ltd and were uncorrected. IR spectra were recorded on infrared spectrophotometer Model Tensor 27, Bruker Co.,Germany,using $\mathrm{KBr}$ discs.UV spectra were recorded on Shimadzu double-beam spectrophotometer UV -210 A using chloroform as a solvent. The theoretical calculations were computed using semi-empirical AM1 module in the CS chem office molecular modeling package.the data obtained from the minimized geometry were used for the theoretical calculations.

\section{Synthesis of 3-acetyl -2H-chromen-2-one ${ }^{[13]}$ (1)}

To a cold mixture of salicylaldehyde $(12.2 \mathrm{~g}, 0.10 \mathrm{~mole})$ and ethylacetoacetate $(13 \mathrm{~g}, 0.10$ mole) was added $1 \mathrm{~g}$ of piperidine With continuous shaking. The solid separated was washed with ethanol. Crystallization of the solid from water gave yellow needle crystals.m.p (121$\left.122^{\circ} \mathrm{C}\right)$ Lit $\left(122^{\circ} \mathrm{C}\right)$ pure 3 -acetyl coumarin.

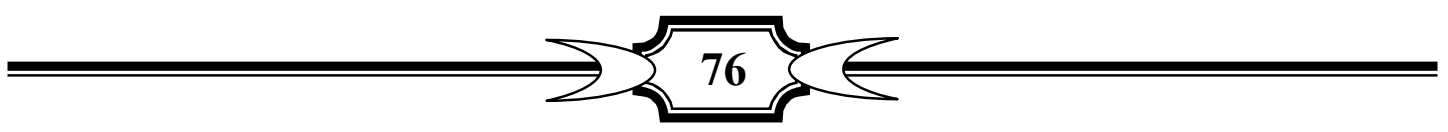


Synthesis of 3-(2-bromoacetyl) -2H-chromen-2-one ${ }^{[14]}$ (2)

A solution of bromine $(4 \mathrm{~g}, 13 \mathrm{ml})$ in chloroform was added by shaking to a solution of 3 -acetylcoumarin $(4.7 \mathrm{~g}, 0.025$ mole) in chloroform. The mixture was heated under reflux for $1 \mathrm{~h}$ and cooled. The solid separated was washed with ether and crystallized from ethanol-chloroform (2:1) gave yellow needle crystals m.p $\left(167-168^{\circ} \mathrm{C}\right) \operatorname{let}\left(164-168^{\circ} \mathrm{C}\right)$.

Preparation of 3- (1H-imidazol-1yl-acetyl) -chromen-2-one ${ }^{[15]}$ (3)

A mixture of 3- (bromo acetyl) )-2H-chromen-2-one $(2.65 \mathrm{~g}, 0.01$ mole) and imidazole $(2.54 \mathrm{~g}, 0.01$ mole $)$ in 1,4 dioxan $(30 \mathrm{~mL})$ was stirred for $2 \mathrm{hrs}$ on magnetic stirrer. The precipitate obtained was filtered, washed thoroughly with acetone and the crude product was recrystallized from ethanol to gave yellow crystalline powder m.p $\left(196-198^{\circ} \mathrm{C}\right)$.

\section{Preparation of $3-[(1 Z)-2-(1 H-i m i d a z o l-1-y l)-1-(2-\quad$ phenyl} hydrazinylidene)ethyl] - chromen-2-one, ${ }^{[16]}$ (4)

A mixture of (1H-imidazol-1yl-acetyl) ) -2H-chromen-2-one (3) $(0.5$ gm, 0.002 mole $)$, phenyl hydrazine $(0.43 \mathrm{~g}, 0.004$ mole $)$ and sodium acetate $(0.3 \mathrm{~g}, 0.004$ mole $)$ in $10-15 \mathrm{~mL}$ of ethanol was refluxed for $2 \mathrm{hrs}$ then cooled. The reaction mixture was poured into ice cold water and the yellow precipitate obtained was filtered and recrystallized from ethanol gave light yellow powder m.p $\left(142-144^{\circ} \mathrm{C}\right)$.

\section{Preparation of 3-[(1Z)-2-(1H-imidazol-1-yl)-1-(2- drazinylidene)ethyl] - chromen-2-one, ${ }^{[16]}(5)$}

A mixture of (1H-imidazol-yl-acetyl) coumarin (3) (0.5 gm, 0.002 mole), hydrazine hydrate (0.2 g. 0.004 mole) and sodium acetate $(0.3 \mathrm{~g}$, 0.004 mole) in $10-15 \mathrm{~mL}$ of ethanol was refluxed for $2 \mathrm{hrs}$ then cooled. The final reaction mixture was poured into an ice cold water and the yellow precipitate obtained was filtered and recrystallized from ethanol to give light yellow crystals m.p $\left(148-150^{\circ} \mathrm{C}\right)$.

\section{3-\{1-[(2,4-Dinitro-phenyl)-hydrazono]-2-imidazol-1-yl-ethyl $\}$-chromen-} 2-one ${ }^{[16]}(6)$

A mixture of (1H-imidazol-yl-acetyl) coumarin (3) (0.5 gm, 0.002 mole), 2,4-dinitrophenyl hydrazine $(0.79 \mathrm{~g}, 0.004$ mole) and sodium acetate $(0.3 \mathrm{~g}, 0.004$ mole $)$ in $10-15 \mathrm{~mL}$ of ethanol was refluxed for $2 \mathrm{hrs}$, cooled. The reaction mixture was poured into an ice cold water and the yellow precipitate obtained was filtered and recrystallized from ethanol to give slight yellow crystals m.p $\left(260-262^{\circ} \mathrm{C}\right)$.

\section{Preparation of imines derived from(1H-imidazol-yl-acetyl)coumarin ${ }^{[17]}$ (7-15)}

A mixture of (1H-imidazol-yl-acetyl) coumarin $(3)(1,27 \mathrm{~g}, 0.005$ mole $)$ and different aromatic amines $(0.005 \mathrm{~mole})$ in $(20 \mathrm{ml})$ absolute ethanol and add one Drop glacial acetic acid then reflux for 3 hours. concentrate the

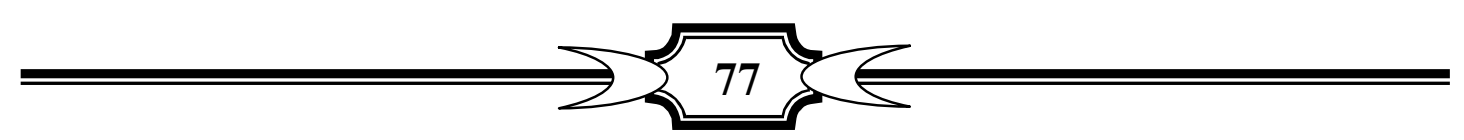


solution for half then cold and The solid separated was washed with water and crystallized from ethanol gave compounds (7-15)

Table(1): some physical properties for compounds (1-3)

\begin{tabular}{|c|l|c|c|c|c|}
\hline $\begin{array}{c}\text { Comp. } \\
\text { No }\end{array}$ & \multicolumn{1}{|c|}{ structure } & color & m.p ${ }^{\circ} \mathrm{C}$ & $\begin{array}{c}\text { Yield } \\
\%\end{array}$ & $\begin{array}{c}\text { m.p }{ }^{\circ} \mathrm{C} \\
\text { lit }\end{array}$ \\
\hline 1 & 3-acetyl coumarin & Needle crystal yellow & $121-122$ & 70 & $122^{[13]}$ \\
\hline 2 & 3-(2-bromoacetyl)coumarin & Needle crystal yellow & $167-168$ & 38 & $163-165^{[14]}$ \\
\hline 3 & $\begin{array}{l}3-(1 \text { H-imidazol-yl- } \\
\text { acetyl)coumarin }\end{array}$ & Crystalline yellow powder & $196-198$ & 65 & \\
\hline
\end{tabular}

Table(2): Some spectral data for compounds(1-3)

\begin{tabular}{|c|c|c|c|c|c|}
\hline \multirow{2}{*}{ Comp.No } & \multicolumn{4}{|c|}{$\mathrm{IR}(\mathrm{KBr}), \mathrm{r}\left(\mathrm{cm}^{-1}\right)$} & $\begin{array}{c}\mathrm{U} . \mathrm{V}\left(\mathrm{CHCl}_{3}\right) \\
\lambda \max (\mathrm{nm})\end{array}$ \\
\cline { 2 - 6 } & $\begin{array}{c}\mathrm{C}=0 \\
\text { lactone }\end{array}$ & $\begin{array}{c}\mathrm{C}=\mathrm{O} \\
\text { acetyl }\end{array}$ & $\mathrm{C}=\mathrm{N}$ & $\mathrm{C}=\mathrm{C}$ & \\
\hline 1 & 1735 & 1700 & & 1635 & 309 \\
\hline 2 & 1740 & 1690 & & 1630 & 304 \\
\hline 3 & 1724 & 1693 & 1604 & 1633 & 312 \\
\hline
\end{tabular}<smiles>[R]N=C(Cn1ccnc1)c1cc2ccccc2oc1=O</smiles>

Compounds $(4,5,6)$

Table (3): some physical properties for compounds (4-6)

\begin{tabular}{|c|c|c|c|}
\hline $\begin{array}{c}\text { Comp } \\
\text {.No }\end{array}$ & $\mathrm{R}$ & m.p ${ }^{\circ} \mathrm{C}$ & Yield\% \\
\hline 4 & $-\mathrm{NH}_{2}$ & $\begin{array}{c}148- \\
150\end{array}$ & 70 \\
\hline 5 & $-\mathrm{NH}-\mathrm{ph}$ & $\begin{array}{c}142- \\
144\end{array}$ & 72 \\
\hline 6 & - & 260 & 65 \\
\hline
\end{tabular}

Table(4): Some spectral data for compounds (4-6)

\begin{tabular}{|c|c|c|c|c|}
\hline \multirow{2}{*}{$\begin{array}{c}\text { Comp. } \\
\text { NO. }\end{array}$} & \multicolumn{3}{|c|}{$\mathrm{IR}(\mathrm{KBr}), \mathrm{r}\left(\mathrm{cm}^{-1}\right)$} & \multirow{U}{*}{$\begin{array}{c}\mathrm{U} . \mathrm{V}\left(\mathrm{CHCl}_{3}\right) \\
\lambda \max (\mathrm{nm})\end{array}$} \\
\cline { 2 - 5 } & $\begin{array}{c}\mathrm{C}=\mathrm{O} \\
\text { lactone }\end{array}$ & $\mathrm{C}=\mathrm{N}$ & $\mathrm{N}-\mathrm{H}$ & 301 \\
\hline 4 & 1710 & 1605 & 3232 & 292 \\
\hline 5 & 1708 & 1600 & 3238 & 310 \\
\hline 6 & 1711 & 1602 & 3225 & \\
\hline
\end{tabular}




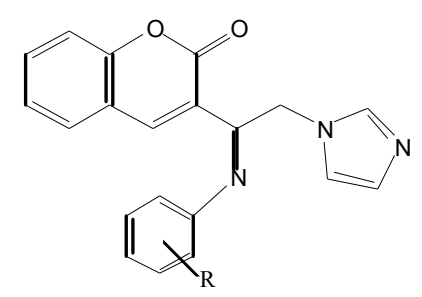

Compounds(7-15)

Table(5): some physical properties for compounds (7-15)

\begin{tabular}{|c|c|c|c|}
\hline $\begin{array}{c}\text { Comp. } \\
\text { No. }\end{array}$ & $\mathrm{R}$ & m.p ${ }^{\circ} \mathrm{C}$ & Yield $\%$ \\
\hline 7 & $\mathrm{H}$ & 102 & 60 \\
\hline 8 & $2-\mathrm{COOH}$ & 110 & 62 \\
\hline 9 & $4-\mathrm{OH}$ & 106 & 70 \\
\hline 10 & $2-\mathrm{NH}_{2}$ & 163 & 60 \\
\hline 11 & $4-\mathrm{CH}_{3}$ & 160 & 55 \\
\hline 12 & $2-\mathrm{OH}$ & 173 & 62 \\
\hline 13 & $3-\mathrm{OH}$ & 142 & 82 \\
\hline 14 & $\mathrm{CH}_{2} \mathrm{CH}_{3}$ & 120 & 52 \\
\hline 15 & $2-\mathrm{Cl}$ & 115 & 66 \\
\hline
\end{tabular}<smiles>[R]c1cccc(/N=C(/Cn2ccnc2)c2cc3ccccc3oc2=O)c1</smiles>

Compounds(7-15)

Table(6):Some spectral data for compounds(7-15)

\begin{tabular}{|c|c|c|c|c|c|}
\hline \multirow{2}{*}{$\begin{array}{l}\text { Comp. } \\
\text { No. }\end{array}$} & \multirow[b]{2}{*}{$\mathrm{R}$} & \multicolumn{3}{|c|}{$\mathrm{IR}(\mathrm{KBr}), \mathrm{r}\left(\mathrm{cm}^{-1}\right)$} & \multirow{2}{*}{$\begin{array}{c}\mathrm{U} . \mathrm{V}\left(\mathrm{CHCl}_{3}\right) \\
\lambda \max (\mathrm{nm})\end{array}$} \\
\hline & & $\begin{array}{l}\mathrm{C}=\mathrm{O} \\
\text { lactone }\end{array}$ & $\mathrm{C}=\mathrm{N}$ & $\mathrm{NH}$ & \\
\hline 7 & $\mathrm{H}$ & 1708 & 1600 & 3325 & 305 \\
\hline 8 & $2-\mathrm{COOH}$ & 1720 & 1600 & 3320 & 302 \\
\hline 9 & $4-\mathrm{OH}$ & 1732 & 1602 & 3340 & 314 \\
\hline 10 & $\begin{array}{l}2-\mathrm{NH}_{2} \\
4-\mathrm{CH}_{3}\end{array}$ & 1719 & 1610 & 3370 & 325 \\
\hline 11 & $2-\mathrm{OH}$ & 1710 & 1595 & 3355 & 302 \\
\hline 12 & $3-\mathrm{OH}$ & 1725 & 1999 & 3365 & 309 \\
\hline 13 & $\mathrm{CH}_{2} \mathrm{CH}_{3}$ & 1730 & 1610 & 3344 & 312 \\
\hline 14 & $2-\mathrm{Cl}$ & 1715 & 1602 & 3360 & 320 \\
\hline 15 & $2-\mathrm{NO}_{2}$ & 1717 & 1604 & 3365 & 333 \\
\hline
\end{tabular}


<smiles>CC(=O)c1cc2ccccc2oc1=O</smiles>

Compound(1)

$$
\text { Compound(2) }
$$<smiles>CC(C)(C)C1CCCCC1</smiles>

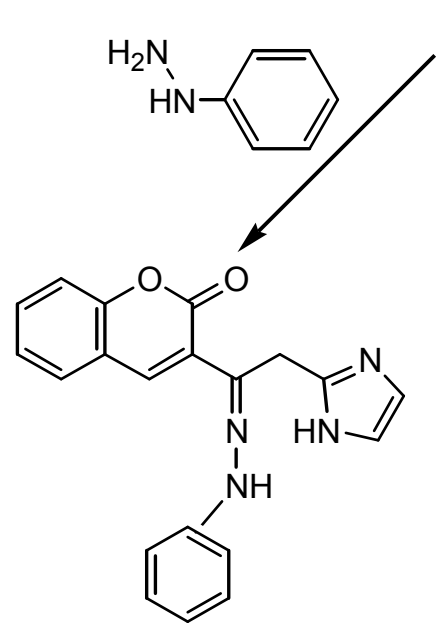

compound(5)<smiles>NN=C(Cc1ncc[nH]1)c1cc2ccccc2oc1=O</smiles><smiles>[R]c1cccc(N)c1</smiles><smiles>[R]c1cccc(N=C(Cc2ncc[nH]2)c2cc3ccccc3oc2=O)c1</smiles>

compound(7-15)

$\mathrm{R}=\mathrm{H}, 2 \mathrm{COOH}, 4-\mathrm{OH}, 2 \mathrm{NO}_{2} \mathrm{CH}_{3}, 2-\mathrm{OH}, 3-\mathrm{OH}, \mathrm{CH}_{2} \mathrm{CH}_{3}, 2-\mathrm{Cl}, 2-\mathrm{NO}_{2}$

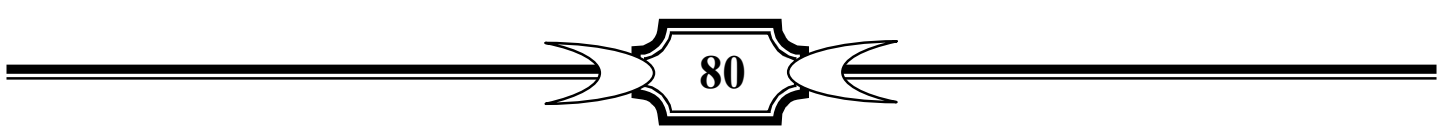




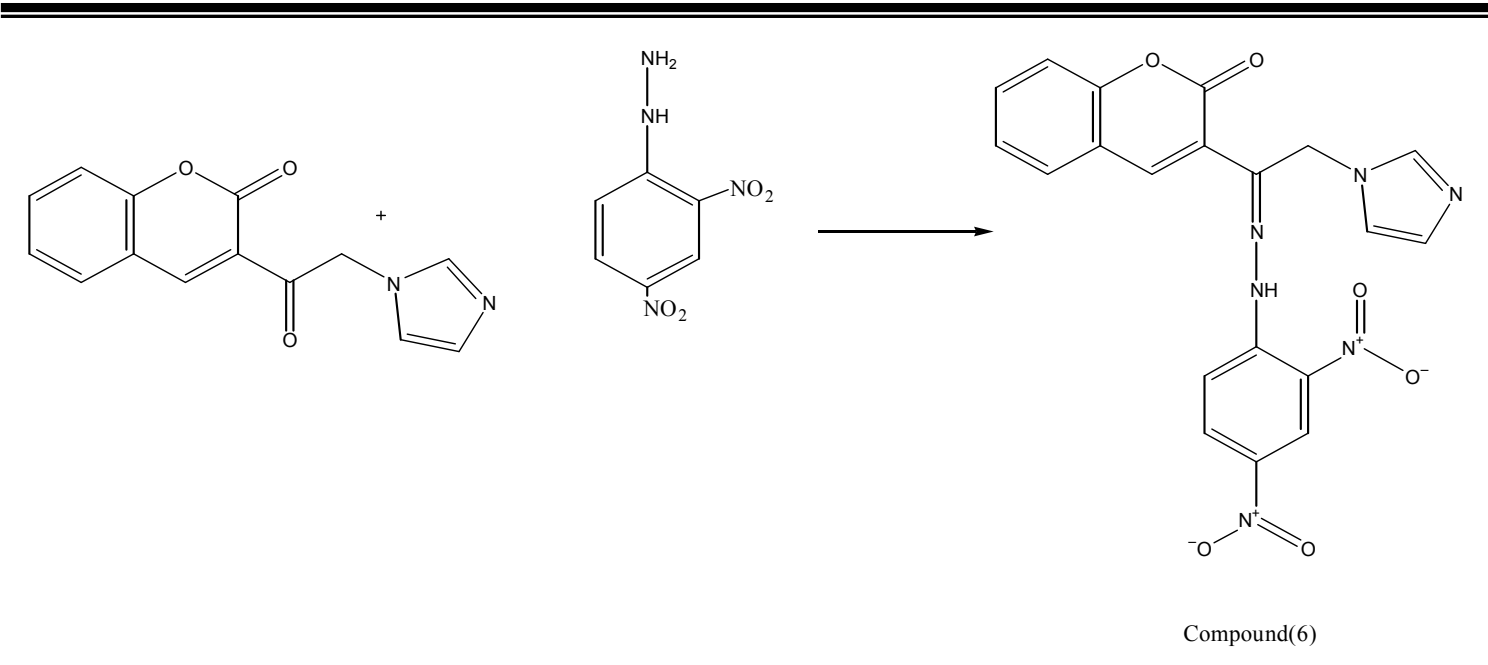

RESULTS AND DISCUSSION

In this study,3-acetyl coumarin and 3-(2-bromoacetyl)coumarin were prepared by section(1,2).3-(1H-imidaol-1yl-acetyl) coumarin (compound(3). compound(3) was elucidated by U.V and infrared spectra(table 2). the I.R spectrum of compound(3) showed $\mathrm{C}=\mathrm{O}$ str. Of lactone at $1724 \mathrm{~cm}^{-1}, \mathrm{C}=\mathrm{N}$ str. Of imidaol at $1604 \mathrm{~cm}^{-1}$ This compound was treated with hydrain hydrate, phenyl hydrazine,2,4-dinitrophenyl-hydrazin to give the compounds $\mathrm{s}$ hydrazon derivatives. The I.R spectrum of 4,5,6 compounds showed $\mathrm{C}=\mathrm{O}$ str. Of lactone at $(1708-1712) \mathrm{cm}^{-1}$ because the conjugated between the double bond in the imine and the double bond in the coumarin, N-H str at $3223 \mathrm{~cm}^{-1} \mathrm{C}=\mathrm{N}$ str. At $(1600-1605) \mathrm{cm}^{-1}$ and disappearance of band at 1693 $\mathrm{cm}^{-1}$ indicated the formation of the compounds the compound (3) was treated with different Aromatic and aliphatic amines to form imines. the I.R spectrum of (7-15) showed $\mathrm{C}=\mathrm{O}$ str. Of lactone approximatly at (1708-1711) $\mathrm{cm}^{-1}, \mathrm{C}=\mathrm{N}$ str.(1595-1610) $\mathrm{cm}^{-1} \mathrm{~N}-\mathrm{H}$ str. (3320-3365). the U.V spectra of compound(3)show $\lambda \max$ at $312 \mathrm{~nm}$ The U.V spectra of compounds(4-6) showed high $\lambda \max$ at $310 \mathrm{~nm}$ due to conjugated between double bond and $\mathrm{CN}$ and the U.V spectra of compounds (7-15) showed high $\lambda \max 333 \mathrm{~nm}$ due to conjugated between double bond and $\mathrm{CN}$.

\section{References}

1) Bruneton J. Pharmacognosy, Phytochemistry, Medicinal Plants. Second Edition, Hampshire UK, Intercept Ltd 1999; pp 263-277.

2) Ojala $\mathrm{T}$. Biological Screening of Plant Coumarins. PhD Thesis, University of Helsinki, 1991

3) Keating G, O'Kennedy R. The Chemistry and Occurrence of Coumarins. Coumarins: Biology, Applications and Mode of Action. (Eds: O'Kennedy R, Thornes RD), Chichester, John Wiley \& Sons, 1997; 23-66.

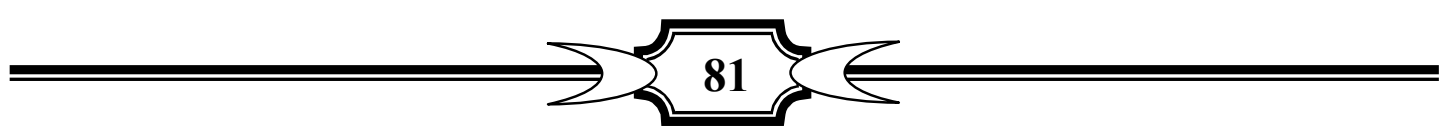


4) Murray RDH, Mendez J, Brown SA. The Natural Coumarins Occurrence, Chemistry and Biochemistry. Chichester, John Wiley, 1982; 43-47.

5) Constantinou AI, Kamath N, Hurley JS. Genistein Inactivates Bcl-2, Delays the G2/M Phase of the Cell Cycle, and Induces Apoptosis of Human Breast Adenocarcinoma MCF-7 Cells. Eur J Can 1998; 34: 1927-1934.

6) Egan D, O'Kennedy R, Moran E, Cox D, Prosser E, Thornes RD. The Pharmacology, Metabolism, Analysis and Applications of Coumarin and Coumarin-Related Compounds. Drug Metab Rev 1990; 22: 503 529.

7) Egan D, O'Kennedy R. Rapid and Sensitive Determination of Coumarin and 7-Hydroxycoumarin and its Glucuronide Conjugate in Urine and Plasma by High Performance Liquid Chromatography. J Chromatogr B 1992; 582: 137-143.

8) Finn G, Kenealy E, Creaven B, Egan D. In vitro Cytotoxic Potential and Mechanism of Action of Selected Coumarins, Using Human Renal Cell Lines. Cancer Letts 2002; 183: 61-68.

9) Lake B. Coumarin Metabolism, Toxicity and Carcinogenicity: Relevance for Human Risk Assessment. Food Chem Tox 1999; 37:423-453.

10) Guilet D, Seraphin D, Rondeau D, Richomme P, Bruneton J.Cytotoxic Coumarins From Calophyllum Dispar. Phytochemistry 2001; 58: 571575.

11) Cooke D, Fitzpatrick B, O'Kennedy R, McCormack $T$, Egan $D$ Coumarins - Multifaceted Molecules with Many Analytical and Other Applications. Coumarins: Biology, Applications and Mode of Action. (Eds: R O'Kennedy, R.D. Thornes), Chichester, John Wiley \& Sons, 1997; pp 303-332.

12) Cooke D. Studies on the Mode of Action of Coumarins (Coumarin,6hydroxycoumarin, 7-hydroxycoumarin and Esculetin) at a Cellular Level. PhD Thesis, Dublin City University, Dublin, Ireland, 1999;2429.

13) Sahu S.K., Mishra A., Behera R.K.: Indian J.Heterocycl. Chem. (1996); 6, 91.

14) C.F. Koelsch, J. Am. Chem. Soc. (1950); 72, 2993-2995.

15) Luis M, Bedoya MB, Rocío S, Dionisio A, Esther D O, José L. \& José A. Bioorg \& Med Chem Lett 2005; 15(20): 4447-4450.

16) Varma RS. Antifungal Agents: Past, Present and Future prospects, (National Academy of Chemistry and Biology, Lucknow, india), (1998); 33-35.

17) A.W.Baker and A.T.Shulgin, J.Chem.Soc., (1959); 81,1524. 